\title{
Christian Albrekt Larsen \\ Et essay om økonomisk ulighed, befolkningens forestillingsunivers og opbakningen til omfordelende velfærdspolitikker
}

Artiklen diskuterer, hvorledes udviklingen i økonomisk ulighed og fattigdom kan påvirke befolkningers forestillingsunivers. Artiklen analyserer USA og Storbritannien, der udmærker sig ved at være blandt de OECD-lande, hvor uligheden og den relative fattigdom er steget mest i perioden fra 1970'erne og frem, og Sverige og Danmark, der udmærker sig ved det modsatte. Der peges på tre centrale områder, der kan være under påvirkning: 1) forestillinger om, hvorvidt samfundsudviklingen har været en "succes" eller "fiasko", 2) forestillinger om, hvorvidt man kan stole på sine medborgere eller ej og endelig 3) forestillinger om, hvorvidt "de fattige" er almindelig mennesker, der har det svært, eller derimod sociale afvigere, der vækker moralsk forargelse. Ved hjælp af surveyundersøgelser illustreres det, hvorledes amerikanerne og briterne på disse tre områder er havnet med et forestillingsunivers, der synes at gøre det vanskeligere og vanskeligere at skaffe politisk opbakning til omfordelende velfærdsstatslige politikker. Det illustreres ligeledes, hvorledes svenskerne og specielt danskerne er havnet med et modsat forestillingsunivers, hvilket skaber en massiv folkelig opbakning til omfordelende velfærdsstatslige politikker.

The American Dream is that dream of a land in which life should be better and richer and fuller for every man, with opportunity for each according to ability or achievement. ... It is not a dream of motor cars and high wages merely, but a dream of social order in which each man and each woman shall be able to attain to the fullest stature of which they are innately capable, and be recognized by others for what they are, regardless of the fortuitous circumstances of birth or position. James Truslow Adams (1931, Epic of America)

Det er et klassisk politologisk spørgsmål, hvorfor nogle befolkninger støtter en stor og omfordelende velfærdsstat, mens andre er langt mere skeptiske. I den politologiske værktøjskasse kan man hente forklaringer på "input-siden" af det politiske system. Forskellene kan fx skyldes partiers og interesseorganisationers mobilisering af befolkningen (Korpi, 1983), dybe kulturelle værdier 
(Lipset 1997) eller graden af etnisk heterogenitet (Alesinar og Glaeser, 2004). Politologien henter imidlertid i stigende grad også sine forklaringer på "outputsiden" af det politiske system. I velfærdsstatsforskningen er det blevet en udbredt opfattelse, at den institutionelle indretning ( $\mathrm{fx}$ hvorvidt ydelser primært gives efter universelle eller selektive kriterier) producerer en betydningsfuldt feedback (fx Pierson, 1993, 2000; Larsen, 2006). Det er også blevet teoretiseret, hvorledes direkte oplevelse med politisk "out-come", fx kvaliteten og organiseringen af velfærdsstatens serviceydelser påvirker holdningsdannelse (fx Kumlin, 2002; Soss, 1999). Nærværende artikel vil med udgangspunkt i denne tradition diskutere, hvorledes udviklingen i den økonomiske lighed og ulighed kan påvirke folkelige forståelser, der er centrale for opbakningen til velfærdsstatslige politikker. Dette vil blive gjort ved at foretage en sammenligning af danskernes, svenskernes, briternes og amerikanernes forståelsesunivers. Disse lande er interessante, da de har bevæget sig i vidt forskellige retninger.

Et stort anlagt OECD-studie af udviklingen i indkomstfordelingen $\mathrm{i}$ de vestlige lande i de seneste tre årtier fik titlen Growing Unequal. Og det var specielt de nordiske lande og de anglesaksiske lande, der fulgte vidt forskellige veje fra 1970'erne og frem. De nordiske lande var de eneste, der formåede ikke at forøge indkomstuligheden over den 30-årige periode. I perioden fra 1967 til 1981 lykkedes det ligefrem i Sverige at reducere den økonomiske ulighed. Målt på den såkaldte gini-koefficient (ækvivalerede disponible indkomster målt via Luxembourg Income Study, herefter LIS) faldt uligheden i Sverige fra 0,26 i 1967 til 0,20 i 1981 (se figur 1). Herefter steg den svenske ulighed frem til 2000, men den nåede ikke op på niveauet fra 1967. I 2005 lå den svenske ulighed lidt under 2000-niveauet. Desværre har vi ikke sammenlignelige danske tal for indkomstfordelingen fra før krisen i 1970'erne (den første danske LISmåling er fra 1987). Nationale historiske kilder viser dog, at indkomstuligheden i Danmark er faldet markant fra 1970 og frem til 2000 (målt på såkaldt udjævningsprocent DØR, 2011: 193). De nyere danske LIS-tal viser, at det lykkes Danmark, som et af de eneste lande i OECD-området, at reducere den økonomiske ulighed i perioden fra midten af 1980'erne til midten af 1990'erne. Herefter er uligheden igen steget svagt (se figur 1). ${ }^{1}$ Helt anderledes ser det ud i de angelsaksiske lande, og i særdeleshed i USA og Storbritannien. Målt på gini-koefficienten steg uligheden i USA fra 0,32 i 1974 til 0,37 i 2004. Og stigningen er endnu kraftigere, hvis man ved hjælp af nationale data går længere tilbage i tiden. I Storbritannien steg gini-koefficienten fra 0,27 i 1969 til 0,35 i 2004, hvilket ligeledes er ganske dramatisk.

De relative fattigdomsrater følger nogenlunde samme mønster. LIS anvender den klassiske internationale standard, hvor fattige defineres som hushold- 
ninger, der har mindre end halvdelen af den indkomst, som en gennemsnitshusholdning har (50 pct. af median disponibel ækvivaleret hustandsindkomst; se LIS hjemmeside for yderligere detaljer). I Sverige i 1967 lå 10,6 pct. af befolkningen under den relative fattigdomsgrænse, hvilket var faldet til omkring 5,6 pct. i 2005. I Danmark faldt andelen af relativt fattige fra 9,9 pct. i 1987 til 5,9 pct. i 2004 (siden da viser nationale data en stigning). I Storbritannien steg andelen af relativt fattige ifølge LIS-data fra 5,5 pct. i 1969 til 11,2 pct. i 2004 (maksimum i midten af 1990'erne). USA havde høje fattigdomsrater i 1970'erne (15 pct. ifølge LIS i 1974), men det blev dog overgået i midten af 1990'erne; i 1997 befandt hele 18 pct. af befolkningen sig under den relative fattigdomsgrænse (fattigdomsrater ikke vist).

Den økonomiske og politiske historie bag den stigende ulighed i USA og Storbritannien og den bevarede lighed i Sverige og Danmark er lang og interessant, men også ganske velbeskrevet. Jeg vil i stedet udforske ideen om, at disse udviklinger $\mathrm{i}$ indkomstuligheden har en effekt på det folkelige forståelsesunivers. Forskning på dette område er i sin vorden, men ikke mindst pub-

Figur 1. Udviklingen i økonomisk ulighed i USA, Storbritannien, Sverige og Danmark. Gini-koefficientera

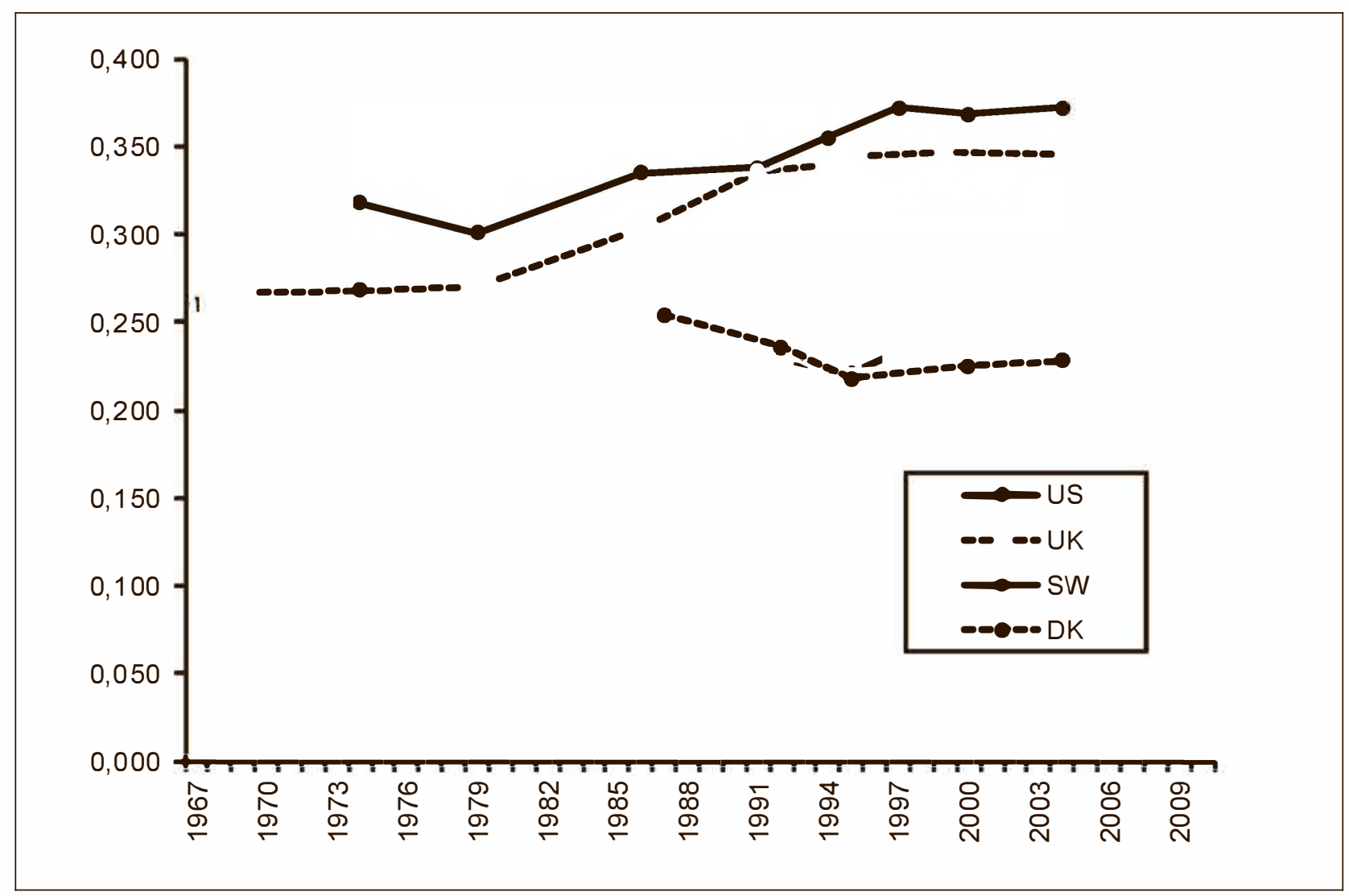

a. Ækvivalerede disponible indkomster fra første til sidste LIS-måling.

Kilde: Hovedindikator fra Luxembourg Income study (http://www.lisdatacenter.org/dataaccess/key-figures/download-key-figures/downloaded 1/11 2012). 
liceringen af bogen The Spiritlevel (Wilkinson og Pickett, 2010) har skabt stor interesse for, hvilke effekter ligheden egentlig har. Min interesse stammer fra en hypotese om, at landene er havnet i en spiral, hvor USA og Storbritannien i takt med stigende indkomstulighed fik sværere og sværere ved at skaffe folkelig opbakning til velfærdsstatslige politikker, og hvor Sverige og Danmark i takt med stigende lighed (indtil for nylig) fik lettere ved at skaffe folkelig opbakning (Larsen, 2006: kapitel 9).

Det er ganske vanskeligt at beskrive, hvorledes udviklingen i uligheden har påvirket henholdsvis amerikanernes, briternes, svenskernes og danskernes forståelsesunivers. Vores surveydata rækker typisk ikke så langt tilbage i tid (der findes kun ganske få repræsentative undersøgelser foretaget før midt-1970’erne) og muligheden for at foretage kvalitative interviews er for længst forpasset. I en sådan situation må man støtte sig til en læsning af landenes historier samt nutidige surveys. Dette er metodikken i det første afsnit, hvor forskelle i befolkningernes "kollektive hukommelse" illustreres med data fra ISSP (International Social Survey Program). En anden mulighed er at læne sig op ad de tidsserier, der trods alt findes. Det er metodikken i de to efterfølgende afsnit, der henholdsvis diskuterer ulighedens indflydelse på tillid og opbakningen til kontanthjælpsydelser. Med hensyn til tillid kan de amerikanske og britiske tidsserier føres tilbage til omkring 1960, mens de svenske og danske kan føres tilbage til 1981, hvor den første World Value Survey stiller det klassiske tillidsspørgsmål. Med hensyn til opbakning til kontanthjælpsydelser kan amerikanske tidsserier føres tilbage til 1973, mens de britiske, svenske og danske kan føres tilbage til midt-1980'erne. I sidstnævnte tidsserier er spørgsmålsformuleringerne ikke identiske, hvorfor de ikke kan bruges til at sammenligne niveauer på tværs af lande. Men de kan bruges til at sammenligne trends i de enkelte lande. Trods disse metodiske begrænsninger vil artiklen forfølge tanken om, at uligheden påvirker forståelsesuniverser. Det anvendte data bruges ikke til at verificere eller falsificere, men til at illustrere ideen om en feedback-effekt fra ulighed og fattigdom.

\section{Den kollektive hukommelse om samfundsudviklingen: Succes eller fiasko}

Et vigtigt parameter for at støtte eller opponere imod velfærdsstatslige politikker er, om sådanne politikker tidligere har været en succes eller en fiasko. En sådan evaluering af tidligere politikker kan kaldes en kollektiv hukommelse eller et kollektivt minde, hvilket Rothstein definerer som "et billede af fortidige begivenheder delt af en begrænset gruppe af mennesker" (egen oversættelse fra Rothstein, 2005: 160). En sådan kollektiv hukommelse er et vigtigt 
rammevilkår for de politiske kampe. Derfor er der altid et politisk strategisk slagsmål om, hvorledes fortiden så ud (se fx Rothstein, 2005: kapitel 7 for en diskussion). For de fleste danskere og svenskere tolkes økonomisk lighed og lave niveauer af fattigdom som en indikator på, at de velfærdstatslige politikker virker. Specielt danskerne lever med en forståelse af, at socialdemokraterne via velfærdsstatslige politikker har "sejret" - måske endda sig selv ihjel. Det er sigende, at målt i 2003 var danskerne det folkeslag (ud af 27 OECD-lande), der var mest stolt af deres velfærdsstat (Larsen, 2008). Svenskerne kom ind på en 11. plads. En anden måde at illustrere det på er ved at se på, hvorledes befolkninger opfatter strukturen af det samfund, som de bor i. I 2009 blev danskerne i den årlige ISSP-undersøgelse bedt om at angive, hvilke af fem diagrammer beskrev det danske samfund bedst (se tabel 1). Af alle medvirkende lande (hidtil samlede data, oktober 2011) havde Danmark den største andel respondenter (57 pct.), der angav Type D: "Et samfund hvor de fleste mennesker befinder sig i midten" (se tabel 1). Det næsthyppigste danske svar, angivet af 25 pct., var Type C: "En pyramide - bortset fra at der kun er nogle få mennesker i den absolutte bund". Kun 10 pct. svarede Type B, mens henholdsvis 2 og 3 pct. svarede Type A og Type E (se tabel). Respondenterne blev også spurgt, hvilket samfund de ville foretrække, hvortil langt hovedparten, 60 pct., svarede Type D. Danskerne har således en udpræget opfattelse af at have det samfund, som de gerne vil have. Svenskernes ønskesamfund ligner stort set danskernes; langt hovedparten svarer også Type D i Sverige. Adspurgt om det faktiske samfund er det hyppigste svenske svar også Type D, angivet af 37 pct., og det næsthyppigste svar er ligesom i Danmark Type C, angivet af 29 pct. Men andelene er mindre end i Danmark, hvilket indikerer en større tvivl om, hvorvidt den gamle socialdemokratiske drøm om folkhemmet blev realiseret. Svenskerne er dog stadig langt mere optimistiske end amerikanerne og briterne (se Larsen, under udgivelse, for analyse af generationseffekter).

I modsætning til danskerne og svenskerne lever mange amerikanere og briter med en kollektiv hukommelse om, at deres samfundsudvikling på nogle områder har været "fejlslagen". Trods the American dream er det kun 27 pct. af amerikanerne, der mener, at de lever i et Type D-samfund, hvor de fleste mennesker befinder sig i midten. I Storbritannien står det endnu værre til. Her der det kun 19 pct., der mener, at de lever i et Type D-samfund. Og Type $\mathrm{D}$ er netop, hvad både hovedparten af amerikanere (49 pct.) og briterne (60 pct.) drømmer om; hvis ikke lige det skulle være for Type E, et samfund med "mange mennesker nær toppen og kun få nær bunden". Ligesom i Danmark og Sverige drømmer stort set ingen om et Type A-samfund, og kun ganske få om et Type B-samfund. Til gengæld oplever mange amerikanere og briter, at de le- 
Tabel 1. Folkelige forestillinger om idealsamfund og faktisk samfund. 2009

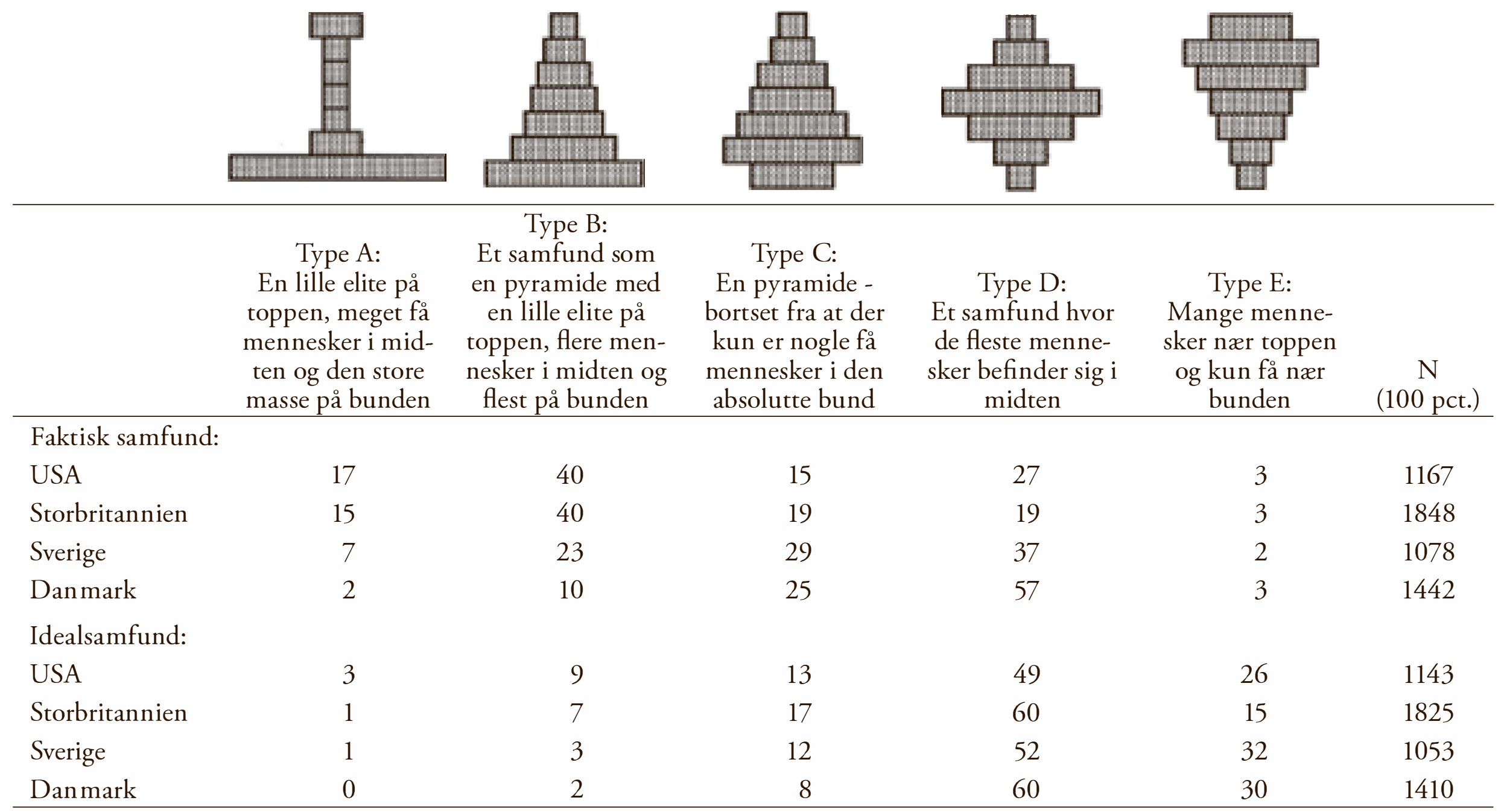

Spørgsmålsformulering: "Først - hvilken type samfund mener du, Danmark (Sverige/USA/, Storbritannien) er i dag - hvilket diagram kommer nærmest?". Dernæst "hvordan synes du, Danmark (Sverige/USA/Storbritannien) burde være - hvilken type ville du foretrække? "Ved for ikke" udeladt. 
ver i sådanne samfund. I begge lande angiver 40 pct. Type B: "Et samfund som en pyramide med en lille elite på toppen, flere mennesker i midten og flest på bunden". I begge lande er det, det hyppigste svar. Henholdsvis 17 pct. af amerikanerne og 15 pct. af briterne angiver Type A, dvs. et samfund med "en lille elite på toppen, meget få mennesker i midten og den store masse på bunden". Det er på ingen måde det samfund, hverken amerikanere eller briter ønsker.

Vi har ikke lange tidsserier på disse spørgsmål, men det er plausibelt, at danskernes og svenskernes opfattelse af at leve i det foretrukne samfund kan stamme fra udviklingen i ulighed beskrevet i indledningen. En "sejr", der i vid udstrækning (i øvrigt ikke uberettiget) tilskrives velfærdsstatens omfordelende mekanismer (fx Korpi og Palme, 1998). Denne kollektive hukommelse om "succes" med den førte politik er formentligt ganske væsentlig for den fortsatte folkelige opbakning til velfærdsstaten og den fortsatte modstand mod (neo-) liberale eksperimenter. Omvendt er det også plausibelt, at amerikanernes og briternes opfattelse af ikke at bo i det ønskede Type D-samfund kan henføres til det den stigende ulighed og fattigdom. Der findes ikke lange amerikanske sammenhængende tidsserier, men det tilgængelig datamateriale indikerer, at troen på muligheden for økonomisk succes er aftagende, specielt blandt afroamerikanere (Hochschild, 1995). Hvorvidt denne "fejlslagenhed" skyldes neoliberale eksperimenter eller derimod de førte velfærdsstatslige politikker (typisk målrettede), har været et permanent diskussionsemne i amerikansk og britisk politik de sidste tre årtier. Det var et trumfkort for Reagan, at Johnsonregeringens war against poverty (1964) var "tabt" i stedet for "vundet". Det samme trumfkort blev spillet i Murrays betydningsfulde bog Losing Ground fra 1984. Ved hjælp af to simple grafer viste Murray, at fattigdommen tilsyneladende voksede i takt med udgifterne til fattigdomsbekæmpende politikker. Murrays konklusion var, at det var politikken, der var årsagen. At amerikanske fattigdomsbekæmpende politikker i 1960'erne og 1970'erne skulle være årsagen til stigende fattigdom i 1980'erne, er i forskningsverdenen et meget lidt anerkendt synspunkt. Ikke desto mindre levede forestillingen videre og var central for AFDC-reformen (kontanthjælpsreformen) i 1996. Diagnosen blev også udbredt til Storbritannien, hvor den ligeledes satte sig betydelige spor i befolkningens forestillinger (Dean og Taylor-Gooby, 1992). Senest er Cameron kommet til magten med henvisning til, at det "fejlslagne" britiske Broken Society kan henføres til de negative bivirkninger af Labours fattigdomsbekæmpende politikker. Disse folkelige kollektive hukommelser om "succes" eller "fiasko" sætter således nogle vidt forskellige rammevilkår for den politiske debat om de velfærdsstatslige politikker. 


\section{Udviklingen i økonomisk ulighed og den gensidige tillid}

Befolkningens vurdering af, hvorvidt man kan stole på hinanden, er en anden central forestilling, der kan påvirkes af udviklingen i den økonomiske ulighed. Det er et standardfund inden for tillidsforskning, at økonomisk lighed er meget stærkt korreleret med tillid (målt på spørgsmålet om, hvorvidt man kan stole på de fleste mennesker eller aldrig kan være forsigtig nok); typisk er sammenhængen stærkere end med nogen andre variable (se fx Rothstein og Uslaner, 2005). Selv Robert Putnam, der har holdt hårdt på teorien om betydning af foreningsdeltagelse, har bidt mærke i sammenfaldet mellem den stigende ulighed beskrevet $\mathrm{i}$ indledningen og amerikanernes tab af tillid til hinanden (2000: 359). Figur 2 viser udviklingen i gensidig tillid i de fire lande baseret på World Value Study og to tidligere observationer fra henholdsvis USA og Storbritannien. I 1960 svarede 55 pct. af amerikanerne, at man kunne stole på de fleste mennesker. Men i slutningen af 1990'erne var det faldet til 36 pct. Hall

Figur 2. Udviklingen i gensidig tillid i USA, Storbritannien, Sverige og Danmark. Andelen, der angiver, at man kan stole på de fleste mennesker

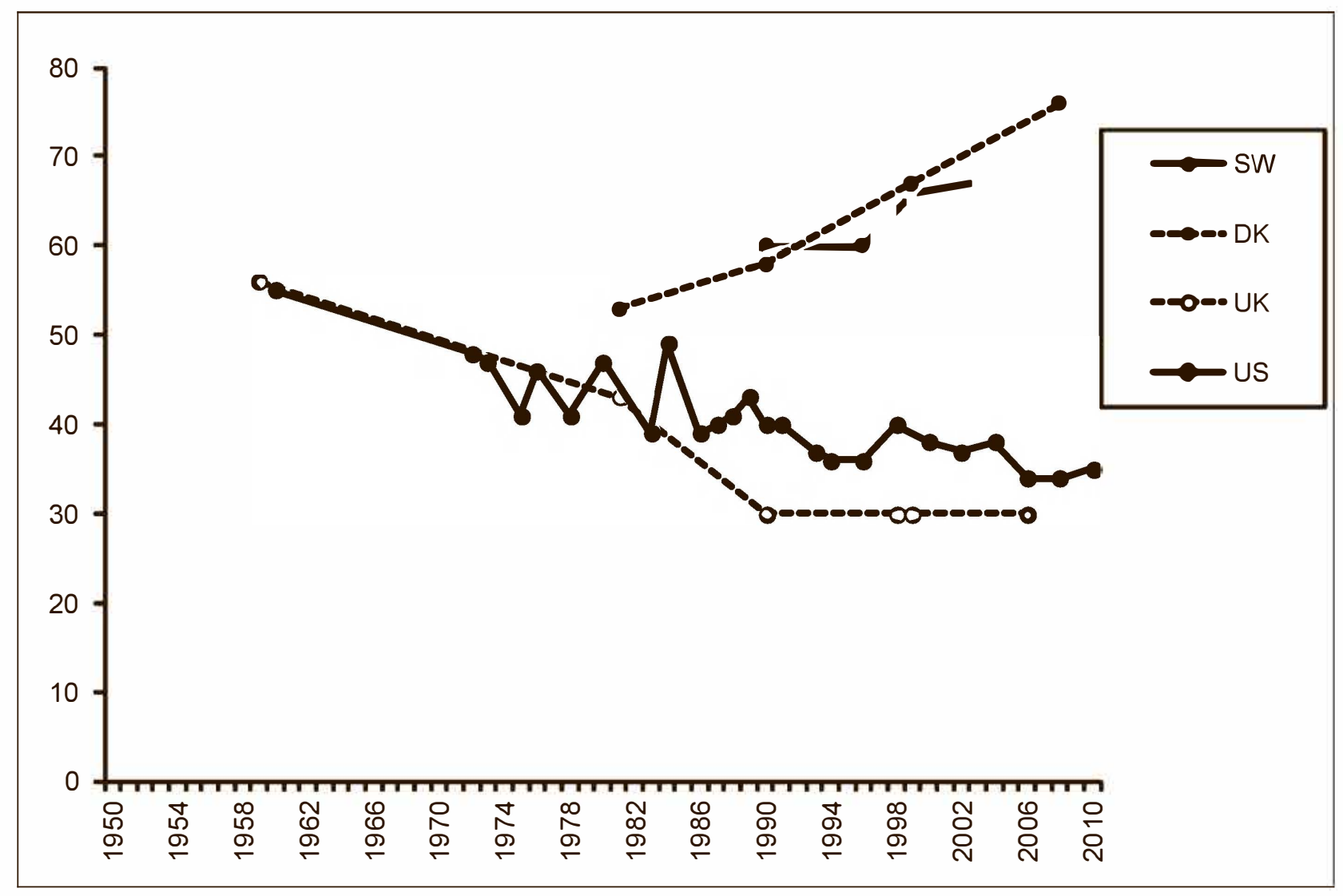

Note: Spørgsmålsformulering: Alt i alt - mener De, at folk er til at stole på, eller mener De, at man ikke kan være for forsigtig, når man har med mennesker at gøre?

Kilde: 1981-2008 World Value Surveys, UK 1959, Hall (1999:432); US 1960, Putnam (2000: 140). 
(1999) kunne genfinde den amerikanske udvikling i Storbritannien. I 1959 sagde 56 pct. af briterne, at man kunne stole på de fleste. I 1990 var det faldet til omkring 30 pct. Det omvendte gør sig gældende i Danmark og Sverige. I 1981 svarede 53 pct. af danskerne og 58 pct. af svenskerne, at man kunne stole på de fleste mennesker. I 2008 og 2007 var det steget til henholdsvis 76 pct. i Danmark og 68 pct. i Sverige. I øvrigt skal det bemærkes, at den mærkelige stigning i USA i 1991 ikke findes i noget nationalt a merikansk surveymateriale (se fx Putnam, 2000 for en god oversigt over nationale amerikanske studier). Det er svært at vurdere, hvor tæt sammenfaldet er mellem trenden i ulighed/ lighed og trenden i tillid. Baseret på mere detaljerede amerikanske data konkluderer Uslaner, at trenden i amerikansk ulighed har en stærk evne til at forudsige tillidsniveauet (2002). Det største problem for "lighedsargumentet" har imidlertid været, at det har stået lidt uklart, hvordan ulighed egentlig påvirker vurderingen af, hvorvidt man kan stole på andre medborgere. Larsen (under udgivelse) foreslår, at sammenhængen kan skyldes, at i økonomisk lige samfund tror de fleste, at andre medborgere tilhører midten, mens det omvendte er tilfældet i ulige samfund, hvor hovedparten af ens medborgere menes at tilhøre "bunden" plus en "top" (jf. tabel 1). Der kan fremføres mange argumenter for, hvorfor man specielt kan have tillid til "midten" (se fx Larsen, 2011), men et første argument er, at langt hovedparten af befolkningerne (også i USA og Storbritannien) mener, at de selv tilhører midten. Og man tenderer til at stole på sine egne. Et empirisk fund, der støtter denne tankegang, er, at der på tværs af lande nærmest er en klar sammenhæng mellem, hvor stor en andel der mener, de lever i et Type D-samfund, og andelen der mener, at man kan stole på de fleste. Nærmere analyse viser også, at sammenhængen er gældende på mikroniveau, dvs. individer, der tror de lever i et Type D-samfund, har større tillid end andre (Larsen, under udgivelse).

Hvor meget af disse udviklinger i tillid, der skyldes udviklingerne i ulighed/ lighed, kan diskuteres. Til gengæld er der nærmest fuldstændig enighed om, at tillid er en vigtig forudsætning for opbakning til velfærdsstaten. Tillid til medborgere forøger tilliden til, at de andre vil betale deres skat, at staten er hæderlig, og at modtagere af ydelser og services ikke snyder. Disse mekanismer om såkaldt betinget opbakning (Levi, 1998) er vist på mange forskellige typer data på tværs af mange forskelle lande. ${ }^{2}$ Både Danmark og Sverige er således havnet $\mathrm{i}$ en situation, hvor den folkelige opbakning til velfærdspolitik hjælpes på vej af stigende tiltro til hinanden, mens det modsatte gør sig gældende i USA og Storbritannien. 


\section{”dviklingen i økonomisk ulighed og opfattelse af "bundgrupperne"}

Befolkningens opfattelse af velfærdsstatspolitikkernes målgrupper er en tredje central forestillingsdimension, der kan blive påvirket af udviklingen i den økonomiske ulighed. Med stigende økonomisk ulighed følger stigende fattigdom, hvilket både i nordiske og angelsaksiske lande opfattes som et betydeligt samfundsmæssigt problem. The American dream var på ingen måde en accept af fattigdom, jf. det indledende citat var det en vision om lighed og opgør med fattigdom. Der er således ikke noget, der får amerikanerne til at føle deres samfund som værende mere "fejlslagent" end stigende fattigdom. I udgangspunkt er både den amerikanske og den britiske befolkning således positivt indstillet over for forsøg på at bekæmpe fattigdom - men også ulighed mere generelt. I 1997 kom Tony Blair fx til magten under slogans om at gøre op med stigende fattigdom og skabe et meritokratisk middelklassesamfund. Tilstedeværelse af fattigdom etablerer således i første omgang en opfattelse af, at noget skal laves om, mens fravær af fattigdom etablerer en folkelig opfattelse af, at noget skal bevares.

Stigende fattigdom påvirker imidlertid også den folkelige opfattelse af, hvem de "fattige" egentlig er, og hvad der egentlig er deres problem. I (rige) ulige samfund er fattige genstand for en kontinuerlig interesse, som ofte ikke gavner den politiske kamp mod fattigdom. En af årsagerne er, at den mediemæssige dækning nemt kan komme til at handle om, hvordan "de fattige" afviger fra majoriteten. Det er en klassisk pointe inden for forskningen i stereotyper. Amerikansk forskning har gentagne gange vist, hvorledes specielt sorte fattige amerikanere afbildes stereotypt i medierne (Gilens, 1996, 2000). I bogen Why Americans Hate Welfare (2000) dokumenterede Gilens, hvorledes amerikanernes modstand mod fattigdomsbekæmpende ydelser hænger sammen med deres negative syn på målgruppen. Og netop økonomisk ulighed kan medvirke til en mere negativ bedømmelse af "bunden". Der er gode indicier på, at økonomisk ulighed skaber mere kriminalitet, stofmisbrug, opbrud i familien og teenagemødre (Wilkinson og Pickett, 2010). Det er ikke altid "de fattige", der er hovedårsagen til de omstændigheder, der skaber "moralsk panik" i offentligheden (Cohen, 1972), fx stofmisbrug. Men de er lette syndebukke. En anden mekanisme er, at stigende ulighed fører til mere boligmæssig segregering, hvilket skaber endnu bedre vilkår for dannelse af negative stereotyper om "de fattige". En tredje mekanisme er, at stigende fattigdom ofte fører til et krav om at målrette de offentlige velfærdsydelser og servicere mere, dvs. logikken "brug kun pengene på dem, der virkelig har brug for det". Startende med Titmuss (1974) har en langforskningstradition dokumenteret de kontraproduktive effekter af 
Figur 3. Modstanden mod at bruge penge på velfærdsydelser målrettet "de fattige”. USA, Storbritannien, Sverige og Danmark

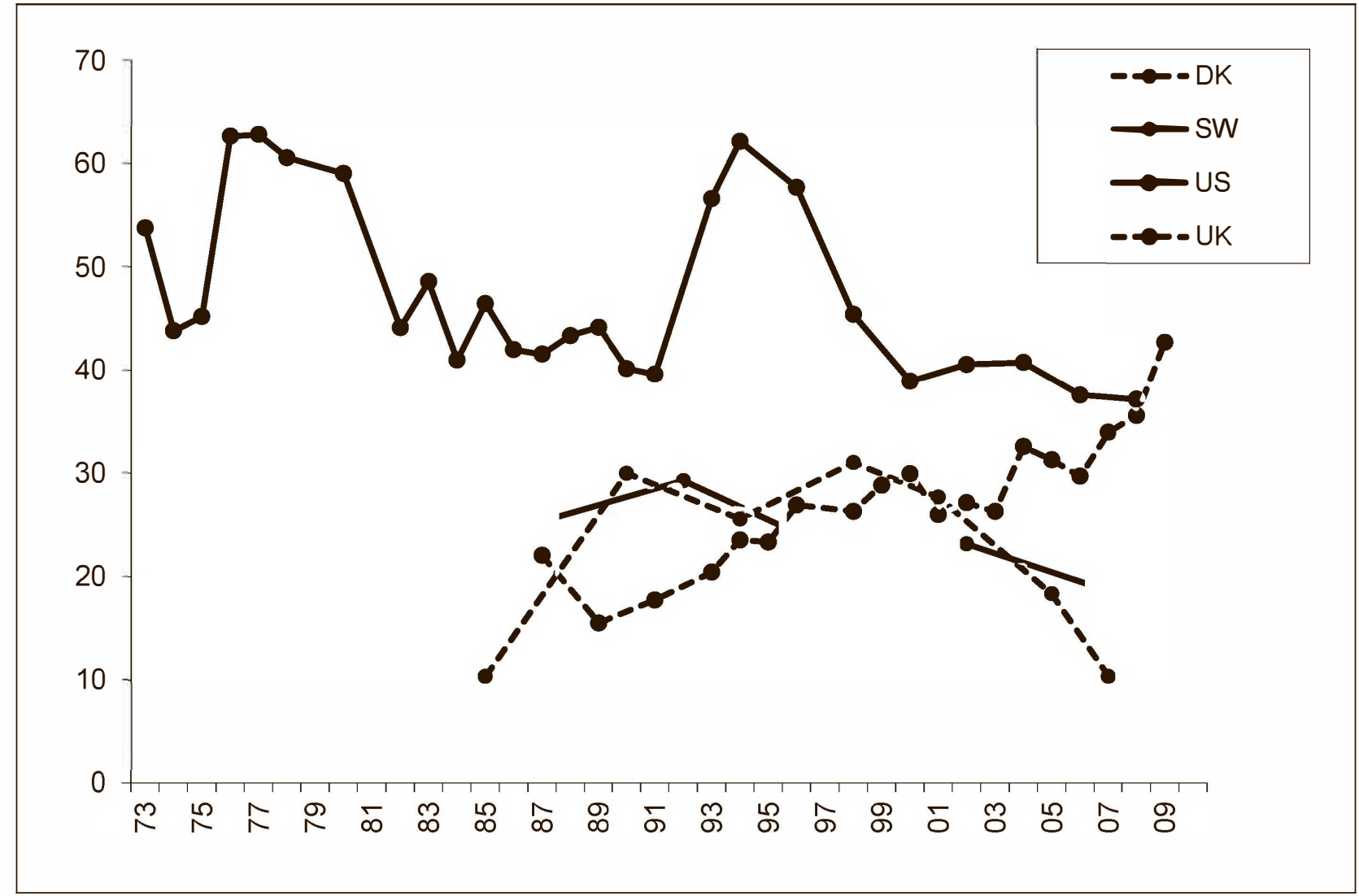

USA: Andel der svarer, at der bliver brugt for mange penge på welfare (Kilde: General Social Survey).

Danmark: Andel der svarer, at der bliver brugt for meget på kontanthjælp (Kilde: Danske valgundersøgelser); 1985 Goul Andersen, Klassestruktur, klassebevidsthed og sociale modsætningsforhold; spm. Formulering afviger lidt, da der spørges til, om niveauet for bistandshjælp er for højt, passende eller for lavt.

Sverige: Andel der svarer, at der bliver brugt for meget på kontanthjælp. (Kilde: Velfærdsstats survey)

Storbritannien: Andel der er "helt uenige" eller "uenige" i, at "regeringen skal bruge flere penge på velfærdsydelser til de fattige, selvom det afstedkommer højere skatter" (egen oversættelse) (Kilde: British Social Attitudes).

"Ved ikke"-svar er udeladt.

målretning i stedet for universalisme (fx Palme og Korpi, 1998; Larsen, 2006; Horton og Gregory, 2009). Senest har Larsen og Dejgaard (2012) dokumenteret, hvorledes fattige og kontanthjælpsmodtagere afbildes langt mere positivt i danske og svenske massemedier end i amerikanske og britiske.

Den stigende ulighed har således ikke ført til mindre amerikansk og britisk modstand mod at bruge penge på "de fattige"; for Storbritanniens vedkommende snarere tværtimod. I USA har der altid været en betydelig opposition mod at bruge penge på de målrettede velfærdspolitikker. I 1973 svarede 53 
pct. af amerikanerne, at regeringen brugte for mange penge på welfare - et begreb, der bruges som fællesbetegnelse for en række målrettede ydelser, hvor den mest betydningsfulde er det nuværende TANF-program (nuværende kontanthjælpsprogram). Lige efter at den økonomiske krise havde ramt i 1970'erne, toppede modstanden med 63 pct., der mente, at der blev brugt for meget på den slags (se figur 3). Da Reagan kom til i 1981 og begyndte at skære i ydelsesniveauerne, faldt andelen, der mente, at der blev brugt for mange penge en smule til omkring og lidt over 40 pct. Men stik imod forventningen svandt oppositionen mod at bruge penge på dette område ikke ind i takt med, at den økonomiske ulighed og fattigdom blev forøget. Tværtimod oplevede USA i starten af 1990'erne en ny kraftig opposition mod at bruge penge på welfare. I 1994 angav 62 pct., at der blev brugt for mange penge. Det var denne folkelige modstand, der fik Clinton til at føre sin første præsidentkampagne under sloganet: "End welfare as we know it". Amerikanerne havde en opfattelse af, at det var velfærdspolitikkerne (i særdeleshed de negative incitamenter i AFCDprogrammet), der havde skabt den "fejlslagne" situation - ikke Reagans neoliberale politik. Murrays diagnose (1984) havde sat sig fast i amerikanerne. Og end ikke AFDC/TANF-reformen (der fx indførte en femårig livstidsgrænse på kontanthjælp) har kunnet ændre den amerikanske opinion (Soss og Schram, 2007).

At fattigdom kan skabe modstand imod fattigdomsbekæmpende politikker, er endnu tydeligere i Storbritannien. Figur 3 viser andelen, der i den britiske BSA-undersøgelse var "uenige" (helt eller delvist) $i$, at regeringen skulle bruge flere penge på de fattige. I 1987 var 22 pct. "uenige" i udsagnet om at bruge flere penge på "de fattige". Da uligheden og fattigdommen toppede i 1998 (et år efter Blair kom til magten) var andelen af "uenige" steget til 26 pct. Og selvom de efterfølgende Labour-regeringer ikke havde stor succes med at reducere den økonomiske ulighed og fattigdom (men dog formåede at levere en tydelig opbremsning), mente flere og flere briter, at der blev brugt for mange penge på "de fattige". I den seneste måling fra 2008 var hele 43 pct. af briterne "uenige" i, at der skulle bruges flere penge på "de fattige". Den stigende opposition imod britiske fattige er glimrende beskrevet af Jones (2011; se også Horton og Gregory, 2009).

Til trods for tilstedeværelsen af generøse fattigdomsbekæmpende politikker i Sverige og Danmark, er der kun ganske få, der ønsker at bruge færre penge på kontanthjælp. Vi har ikke helt så lange tidsserier som i USA og Storbritannien. Men i 2009 angiver kun 16 pct. af svenskerne, at der bruges for mange penge på kontanthjælp. Modstanden var større i starten af 1990'erne, hvor 29 pct. svarede, at der blev brugt for mange penge på kontanthjælp (1992). 
Denne "top" kan muligvis forklares med den svenske økonomiske krise, der nødvendiggjorde besparelser i hele den svenske velfærdsstat. I Danmark er situationen stort set den samme. Vi har et datapunkt i 1985. Det er ikke helt sammenligneligt med det efterfølgende spørgsmål i valgundersøgelserne, da der spørges til, hvorvidt niveauet for bistandshjælp er for højt, passende eller for lavt, og ikke hvorvidt der bruges for mange, passende eller for få penge på området. Det er dog interessant, at i 1985 var det kun 10 pct. af befolkningen, der mente, at niveauet for bistandshjælp var "for højt". I 1990 mente omkring 20 pct., at der blev brugt for mange penge på kontanthjælp til den enkelte. Fra dette niveau faldt andelen til 16 pct. i 2005 og 9 pct. i 2007, hvilket formentlig er en reaktion på, at VK-regeringen begyndte at skære i kontanthjælpsydelser til indvandrere.

\section{Den politiske logik i de to udviklingsveje}

Ovenfor er der argumenteret for, at det kollektive minde om samfundsudviklingen som en "succes" eller "fiasko", borgernes tillid til hinanden og opfattelsen af velfærdspolitikkernes målgrupper er påvirket af udviklingen i økonomisk ulighed. Hvorvidt dette kausalforhold er sandt eller falsk, er vanskeligt at dokumentere, men i mindste er der påvist en række interessante empiriske sammenfald. Og tror man på kausalforholdet, åbner det for en lang række interessante teoretiske diskussioner. Den mest oplagte er, at man via en kraftig forøgelse af den økonomiske ulighed kan igangsætte en selvforstærkende kurs. Forøgelse af ulighed og fattigdom flytter et samfund væk fra det, som ønskes af hovedparten af befolkningen. Denne folkelige opfattelse af "fejlslagenhed" kommer nemt til at fungere som et rammevilkår for de politiske diskussioner. Det behøver ikke nødvendigvis at betyde mindre opbakning til velfærdspolitikker. Men det er en mulighed, da velfærdspolitikker potentielt kan blive opfattet som en del af problemet. Sker der samtidig et fald i befolkningens tillid til hinanden og en negativ stereotypisering af samfundets bundgrupper, så kan det være overordentlig vanskeligt at skaffe folkelig opbakning til målrettede fattigdomsbekæmpende politikker som kontanthjælp. Til gengæld bliver det i en sådan situation lettere og lettere at skaffe folkelig opbakning til at give hårde straffe. Den straffende politik skal rette op på det "fejlslagne" samfund, beskytte mod snyd og normalisere de afvigende bundgrupper (Wacquant, 2009). Det synes at være den situation, som både USA og Storbritannien er "låst fast" i. Og de seneste optøjer i Storbritanniens fattige kvarterer har kun gjort situationen endnu mere politisk fastlåst.

Sverige og Danmark synes at være "låst fast" i den modsatte situation. Den økonomiske lighed har skabt en oplevelse af samfundsudviklingen som en "suc- 
ces”, hvilket etablerer helt anderledes rammevilkår for den politiske diskussion. Rammen har været, hvordan man skal bevare og udbygge de velfærdsstatslige politikker, som synes at have forårsaget denne "succes" eller "nordiske model" - de sidste to termer bruges nogle gange nærmest i flæng i den politiske debat. Og Danmark er det mest sigende eksempel. Det er ganske vanskeligt at overbevise danskerne om de negative effekter af velfærdsstatslige politikker (ifølge min overbevisning med rette, men jeg er jo også dansker), og derfor er nedskæringsønsker ofte pakket ind i en retorik om, at man skal "lave om for at bevare" vores "succes" eller "model". Kombineret med stigende tillid og en yderst positiv opfattelse af samfundets bundgrupper (kritiske røster vil sige positivt stereotypiserende, se Larsen og Dejgaard, 2012) bliver resultatet, at politikerne står over for en nærmest uopslidelig opbakning til velfærdsstatslige politikker generelt og en stabil opbakning til målrettede fattigdomsbekæmpende ydelser specifikt. I perioden fra 2003 til 2008 steg den økonomiske ulighed og andelen af relative fattige i Danmark (DØR, 2011). Man kan godt iagttage enkelte amerikanske og britiske tendenser, $f_{x}$ en intensiveret gøren grin med socialt marginaliserede og en offentlig diskussion om, hvorvidt "Karina" får for meget i kontanthjælp (en enlig mor, der fik stor mediebevågenhed i 2011). Men der skal efter min vurdering mere til at omstyrte det nordiske forestillingsunivers. En god indikation på det er, at de fleste danskere og svenskere fortsat er ret forbeholdne over for at løse den økonomiske uligheds sociale problemer ved hjælp af hårdere og hårdere straffe. Forøget afstraffelse af samfundets bundgrupper er et klassisk tegn på et samfund, der har mistet tiltroen til velfærdspolitikker. Der er Danmark ikke endnu.

\section{Noter}

1. Herefter viser LIS dataene stigende ulighed frem til 2000 og 2004, men dog ikke op til et niveau over udgangspunktet i 1987. Det samme resultat findes i nationale data (blandt andet med brug af anderledes ækvivalensskala); dog med den tilføjelse af den stigende ulighed fra 2003 til 2008 fik den danske gini-coefficient over niveauet fra midt-1980'erne. Det rykker dog ikke ved, at uligheden set i det lange perspektiv fra 1970 til nu har været faldende.

2. Se Rothstein (2005) for argumentet om, at det er statsinstitutionerne, og specielt retssikkerheden i universalismen, der skaber tillid. Der er et vist empirisk belæg for den forklaring (Kumlin og Rothstein, 2005).

\section{Litteratur}

Alesina, Alberto og Edward Glaeser (2004). Fighting Poverty in the US and Europe: A World of Difference. Oxford: Oxford University Press. 
Cohen, Stanley (1972). Folk Devils and Moral Panics. London: MacGibbon and Kee.

Dean, Hartley og Peter Taylor-Gooby (1992). Dependency Culture: The Explosion of a Myth. New York: Harvester Wheatsheaf.

DØR (2011). Dansk Økonomi, efterår 2011. København: Det Økonomiske Råd.

Gilens, Martin (1996). Race and Poverty in America. Public Misperceptions and the American News Media. Public Opinion Quarterly 60: 515-541.

Gilens, Martin (2000). Why Americans Hate Welfare. Race, Media, and the Politics of Antipoverty Policy. Chicago: University of Chicago Press.

Hall, Peter (1999). Social Capital in Britain. British Journal of Political Science 29: 417-461.

Hochschild, Jennifer L. (1995). Facing Up to the American Dream: Race, Class, and the Soul of the Nation. Princeton: Princeton University Press.

Horton, Tim og James Gregory (2009). The Solidarity Society. Why We Can Afford to end Poverty, and How To Do It with Public Support. London: Fabrian Society.

Jones, Owen (2011). Chavs. The Demonization of the Working Class. London: Verso. Korpi, Walter (1983). The Democratic Class Struggle. London: Routledge and Kegan Paul.

Korpi, Walter og Joakim Palme (1998). The Paradox of Redistribution and Strategies of Equality: Welfare State Institutions, Inequality, and Poverty in the Western Countries. American Sociological Review 63 (5): 661-687.

Kumlin, Stefan (2002). The Personal and The Political: How Personal Welfare State Experiences Affect Political Trust and Ideology. Department of Political Science, Göteborg university.

Kumlin, Stefan og Bo Rothstein (2005). Making and Breaking Social Capital. The Impact of Welfare-State Institutions. Comparative Political Studies 38 (4): 339-365.

Larsen, Christian Albrekt (2006). The Institutional Logic of Welfare Attitudes. London: Ashgate.

Larsen, Christian Albrekt (2008). Danskernes nationale forestillinger. Aalborg: Aalborg Universitetsforlag.

Larsen, Christian Abrekt (2011). Typer af velfærdssamfund, social kapital og tillid, i Paul Hegedahl og Gunnar L.H. Svendsen (red.), Tillid - samfundets fundament. Teorier, tolkninger, cases. Odense: Syddansk Universitetsforlag.

Larsen, Christian Albrekt (under udgivelse). The Rise and Fall of Social Cohesion. The Construction and De-construction of Social Trust in the US, UK, Sweden and Denmark.

Larsen, Christian Albrekt og Thomas Dejgaard (2012). The Institutional Logic of Images of the Poor and Welfare Recipients. A Comparative Study of British, Swedish and Danish Newspapers. CCWS Working Paper No. 78. Aalborg: CCWS, Aalborg Universitet. 
Levi, Margaret (1998). Consent, Dissent, and Patriotism. New York: Cambridge University Press.

Murray, Charles (1984). Losing Ground. American Social Policy 1950-1980. New York: Basic Books.

Lipset, Seymour Martin (1997). American Exceptionalism. A Double-Edged Sword. New York: W.W. Norton \& Company.

OECD (2008). Growing Unequal? Income Distribution and Poverty in OECD Countries. Paris: OECD.

Palme, Joakim og Walter Korpi (1998). The Paradox of Redistribution and Strategies of Equality: Welfare State Institutions, Inequality, and Poverty in the Western Countries. American Sociological Review 63 (5): 661-687.

Pierson, Paul (1993). When Effect Becomes Cause: Policy Feedback and Political Change. World Politics 45: 595-628.

Pierson, Paul (2000). Increasing Returns, Path Dependence, and the Study of Politics. American Political Science Review 94 (2): 251-267.

Putnam, Robert D. (2000). Bowling Alone. The Collapse and Revival of American Community. New York: Simon and Schuster.

Rothstein, Bo (2005). Social Traps and the Problem of Trust. Cambridge: Cambridge University Press.

Rothstein, Bo og Eric M. Uslaner (2005). All for All. Equality, Corruption and Social Trust. World Politics 58 (1): 41-72.

Soss, Joe (1999). Lessons of Welfare: Policy Design, Political Learning, and Political Action. American Political Science Review 93 (2): 363-380.

Soss, Joe og Sanford F. Schram (2007). A Public Transformed? Welfare Reform as Policy Feedback. The American Political Science Review 101 (1): 111-127.

Titmuss, Richard M. (1974). Social Policy: An Introduction. London: Allen and Unwin. Uslaner, Eric. M. (2002). The Moral Foundations of Trust. Cambridge: Cambridge University Press.

Wacquant, Lois J. D. (2009). Punishing the Poor: The Neoliberal Government of Social Insecurity. Durham: Duke University Press Books.

Wilkinson, Richard og Kate Pickett (2010). The Spirit Level. Why Equality is Better for Everyone. London: Penguin Books 